Relations industrielles

Industrial Relations

\title{
Individuals’ Assessment of Corporate Social Performance, Person-Organization Values and Goals Fit, Job Satisfaction and Turnover Intentions
}

\section{Appréciation de la performance sociale de l'entreprise par les employés, adéquation employé-organisation en matière de valeurs et d'objectifs, satisfaction au travail et intention de quitter son emploi Evaluación individual del desempeño social de la empresa, adecuación persona-organización en cuanto a valores y objetivos, satisfacción del trabajo e intención de dejar su empleo}

Sarah Hudson, Douglas Bryson et Marco Michelotti

Volume 72, numéro 2, printemps 2017

URI : https://id.erudit.org/iderudit/1040403ar

DOI : https://doi.org/10.7202/1040403ar

Aller au sommaire du numéro

Éditeur(s)

Département des relations industrielles de l’Université Laval

ISSN

0034-379X (imprimé)

1703-8138 (numérique)

Découvrir la revue

Citer cet article

Hudson, S., Bryson, D. \& Michelotti, M. (2017). Individuals' Assessment of Corporate Social Performance, Person-Organization Values and Goals Fit, Job Satisfaction and Turnover Intentions. Relations industrielles / Industrial Relations, 72(2), 322-344. https://doi.org/10.7202/1040403ar
Résumé de l'article

Des recherches récentes dans le domaine de la responsabilité sociale de l'entreprise (RSE) ont souligné l'importance de ne pas se limiter à une perspective purement institutionnelle de la RSE et de se tourner vers le niveau micro. Elles insistent également sur la nécessité de développer une compréhension plus approfondie, ainsi que plus nuancée, des impacts et des mécanismes sur les individus. Notre article prend en compte cet enjeu en s'attardant à l'étude de la relation entre l'appréciation que font les employés de l'actuelle RSE dans le cas de leur propre entreprise et la manière dont cette appréciation peut influer sur des résultats individuels ou de niveau micro, tels la satisfaction au travail et l'intention de quitter ou pas son emploi. Nous abordons cette question en étudiant la façon dont l'adéquation perçue entre les employés et leur organisation induit la relation entre la perception de la performance sociale de l'entreprise (PSE), d'une part, et la satisfaction au travail ou l'intention de quitter son emploi, d'autre part.

Une notion communément reprise dans la littérature soutient que la performance sociale des entreprises peut avoir des effets bénéfiques sur les employés au niveau individuel, cependant peu d'études empiriques se sont penchées sur les mécanismes en cause. Afin de combler cette lacune, nous analysons les données quantitatives d'une enquête menée auprès de 317 jeunes employés oeuvrant dans des entreprises de tailles et de secteurs différents en Europe et en Asie. Nous observons qu'une appréciation positive de la PSE n'exerce pas une influence directe sur la satisfaction au travail ni sur l'intention de démissionner, mais qu'elle influe sur la relation employé-entreprise. Cette dernière, à terme, exerce une influence positive sur ces facteurs, soit la satisfaction au travail et l'intention de demeurer dans son emploi.

Ces résultats montrent qu'une performance efficiente et efficace de l'entreprise en ce qui a trait à ses responsabilités sociales et environnementales renforce la perception de la part des employés qu'il y a adéquation entre leurs valeurs et celles de l'entreprise. Ce processus crée donc de la valeur en augmentant la satisfaction au travail et en diminuant l'intention de quitter l'organisation. Nous avons également noté que le simple fait d'améliorer la PSE d'une manière objective, sans une implication et une conscientisation accrue des employés, ne mènera pas nécessairement à améliorer l'adéquation entre les employés et leur organisation ni aux résultats désirables auxquels on aurait pu s'attendre.
Tous droits réservés (C Département des relations industrielles de l’Université Laval, 2017
Ce document est protégé par la loi sur le droit d'auteur. L’utilisation des services d'Érudit (y compris la reproduction) est assujettie à sa politique d'utilisation que vous pouvez consulter en ligne.

https://apropos.erudit.org/fr/usagers/politique-dutilisation/ 


\section{Individuals' Assessment of Corporate Social Performance, Person-Organization Values and Goals Fit, Job Satisfaction and Turnover Intentions}

\section{Sarah Hudson, Douglas Bryson and Marco Michelotti}

The relationship between employees' assessment of corporate social performance (CSP), perceived person-organization fit, job satisfaction and turnover intention is studied. We analysed quantitative survey data from 317 young employees from differing company sizes and sectors in Europe and Asia using simple correlation techniques followed by structural equation modelling (SEM). The key finding of this work is that positive assessment of CSP does not have a direct influence on job satisfaction and turnover intention, but acts through the mechanism of person-organization fit, which in turn has a positive effect on job satisfaction and reduced turnover intention.

KEYWORDS: corporate social performance, corporate social responsibility, person-organization fit (PO fit), job satisfaction, structural equation modelling (SEM), turnover intention.

\section{Introduction}

Over the past few decades, there has been a growing recognition amongst social science scholars and policy makers that the activities of a firm have wide implications for society as a whole, with these activities extending well beyond profit making and serving the interests of a small group of stakeholders. As a result, academics and practitioners have begun to investigate the ethical and socially responsible behaviour of companies, and are also seeking to develop measurement instruments for Corporate Social Performance (CSP) (Brammer et al., 2007; Donaldson and Preston, 1995). CSP differs from corporate social responsibility 
(CSR) in that it defines the actions and outcomes of the economic, social and environmental responsibilities included within the concept of CSR (Wood, 1991).

While there is a substantial body of research work that studies CSR and CSP at an institutional level, there is limited research investigating the nexus between individuals' assessment of corporate social performance and its relationship with employee outcomes. It is worth investigating this in more detail because there is a well-established link between individual values, person-organization fit (PO-fit), employee satisfaction and job turnover. At an individual level, CSP can be assessed on the basis of personal values (Gond et al., 2017), so it is reasonable to assume that positive individual assessments of CSP will have a positive effect on employee outcomes, with this relationship being possibly mediated by the ways in which an employee fits with the overall organization.

Against this background, the primary aim of this paper is to investigate the relationship between employee assessment of CSP, PO-fit, job satisfaction and turnover intention. In order to do so, the paper is structured in the following way. The first section will consider the association between CSR and CSP. Section two will then proceed to analyse the literature on PO-fit and employee outcomes. Particular emphasis will be placed on job satisfaction and employee turnover. Section three will then develop six hypotheses that are tested and discussed in the final two sections.

\section{Corporate Social Responsibility, Corporate Social Performance, and Employee Outcomes}

Behaving responsibly towards company stakeholders and the environment is sometimes difficult, time consuming and costly for companies. However, corporate acceptance of behaving responsibly does not necessarily mean the time expended and the financial costs associated with these activities are for naught. Several research streams have been generated with the objective of better understanding the links between corporate social responsibility (CSR) and financial performance (Wu, 2006), attractiveness to investors (Shaw et al., 2005), corporate image (Riordan et al., 1997), and ethical fit of companies and employees (Coldwell et al., 2008; Sims and Kroeck, 1994).

One particular strand of CSR research focuses on the nexus between CSR and employee outcomes. This literature mainly investigates two issues: 1- the extent to which CSR influences employee job satisfaction, motivation, trust and commitment (Brammer et al., 2007; Greening and Turban, 2000; Turban and Greening, 1997; Vlachos et al., 2014); and 2- the effects of CSR activities on job seekers' behaviour and attitudes, and perceived organizational attractiveness (Albinger and Freeman, 2000; Jones et al., 2014). 
Recently, there have been renewed calls for more extensive research into CSR and employee outcomes, with particular emphasis being placed on exploring the underlying psychological mechanisms of this relationship. For example, Morgeson et al. (2013) insist that there is a need to explore this relationship at a more disaggregated level, including individual employee, job applicant or manager level issues. This is so, Morgeson et al. (2013) claim, for two main reasons: 1- studies of CSR have tended to focus on macro-level topics such as governance, strategy and finance; and 2- most of this research views employees and job-seekers as a group rather than as individuals. The authors strongly encourage the adoption of a more psychological approach-using subjective measures of CSR- based on Rupp et al.'s (2013) suggestion that employees' perceptions of their employing organizations' social actions might be more salient than assessing organizations' objective CSR performance. Their call has been recently addressed by studies investigating, for example, the interaction between organizational prestige, pride and the level of employee identification (De Roeck et al., 2016) and other similar variables (Vlachos et al., 2014).

The growing interest in CSR-individual or micro-level research also emerges in a recent and comprehensive study by Gond et al. (2017) who review the relationship between CSR and a whole raft of individual-level outcome variables. More specifically, CSR seems to have a positive effect on employee attitudes such as organizational commitment, job satisfaction, employee engagement, justice or perceived work-life quality, and is associated with lower turnover intentions. CSR also positively links to behaviours such as organizational citizenship and creativity. Importantly, Gond et al. (2017) emphasize that while identification with the organization is generally assumed to be the primary mechanism through which CSR and employee outcomes are linked, very few studies have tested this relationship.

As such, the first contribution of this paper lies in expanding upon existing research into employee perceptions of CSR and the associated effects on employee outcomes (Rupp et al., 2013). We do this by exploring the extent to which a specific type of organizational identification, the degree to which individuals perceive they fit with the goals and values of their organization, influences job satisfaction and turnover intention. By doing so, we also contribute to assessing a widely evoked, but rarely tested hypothesis, namely that PO-fit is one of the mechanisms though which CSR links to individual employee outcomes (Gond et al., 2017).

Although loosely defined, there are a number of features that are common to most conceptualizations of CSR. First, CSR can be ethical, normative, legal, economic and discretionary in nature. Second, CSR extends the range of activities of firms to several domains that include, but are not limited to, social issues, 
the environment, consumer safety, and employee well-being. Third, the level of responsiveness of firms to social issues needs to be measured (Shaw et al., 2005; Wu, 2006; Zyglidopoulos et al., 2016).

The latter is a particularly important aspect for the purpose of this paper because it highlights the need to develop instruments to assess the social performance of firms. Again, while there are different definitions of CSP, a consensus has been forged around the notion that assessments of CSP should include three main components: 1- integration of CSR principles; 2- firm social responsiveness; and 3- effectiveness of outcomes (Wood, 1991). The first component should assess the extent to which principles of social responsibility are integrated into firms' practices. An example of this would be by examining the degree to which a company acts on a principle of balancing stakeholder interests rather than maximizing profit. The second should aim to evaluate the level of social responsiveness of firms. This can correspond, for example, to the methods used by a firm to respond to social demands for environmental responsibility. The third component should assess the level of effectiveness of the policies developed to address CSR concerns (Wartick and Cochran, 1985). In short, while CSP may well include processes and principles that can be inferred, visible or concrete components of CSP are the outcomes. Such outcomes represent the core of CSP and have been investigated both conceptually and empirically (Carroll, 1979; Clarkson, 1995; Wood, 1991). For example, various studies and conceptual papers have investigated CSP links with variables such as corporate reputation (Carroll and Buchholtz, 2000), financial performance (Wang and Berens, 2015), employee commitment (Brammer et al., 2007), and PO-fit (Herrbach and Mignonac, 2007; Sims and Kroeck, 1994).

The latter relationship is central for the purpose of this paper, and research on it deserves development for two main reasons. First, the CSP-PO-fit link has mostly been explored at the conceptual level (Coldwell et al., 2008; Rupp et al., 2006). This is principally because CSP is a multi-dimensional concept that is inherently difficult to operationalize. Consequently, the collection of reliable data remains problematic. For example, while Coldwell et al. (2008) make a strong theoretical case to support a link between CSP, quality of job applications and low turnover, very little is explained on how to measure most of the variables or the relationships amongst them. Second, there is a lack of interdisciplinary research because CSP tends mostly to be studied within the CSR-strategy literature while PO-fit is salient for HRM management scholarship. For example, while Herbach and Mignonac (2007) empirically test a number of factors related to CSP, their analysis is limited to exploring the nexus between ethical values and employee outcomes. Even when more complex models investigating the relationship between CSR and some aspects of PO-fit are tested, their focus remains firmly centred on a few specific issues such as CSR or corporate culture fit (Lee et al., 
2013). As valuable as these contributions are, they are plagued by two major shortcomings: 1 - the constructs considered relate only to CSR and employee attitudes; and 2- they neglect to assess how these relationships are mediated by specific HRM factors such as motivation, personality and vocation. These factors are the domain of PO-fit research to which we now turn.

\section{Corporate Social Performance, Person-Organization Fit, and Employee Outcomes}

There is a certain appeal to the idea that a good fit between a person and his environment or organization will result in positive employee outcomes (Chen et al., 2016; Ostroff and Schulte, 2007). In particular, the construct of PO-fit has been defined as "the congruence between the norms and values of organizations and the values of persons" (Chatman, 1989: 339). The manner in which fit can be determined has been the subject of considerable attention and debate. KristofBrown and Jansen (2007) claim that fit can be differentiated into two types. The first is objective fit, where there can be an external assessment or measurement of matching between organizational and individual values and goals. The second is subjective fit, often referred to as perceived fit, where individual respondents provide their own overall assessment of how they fit with the work environment or organization in terms of values and goals (Cable and Judge, 1997; 1996). We focus here on perceived fit, noting that both value and goal congruence measures have been extensively used to measure perceived PO-fit (Colbert et al., 2008; Vancouver and Schmitt, 1991) and that this is the approach also taken in this research.

The domain of PO-fit holds a central tenet that "human behaviour is a function of the interaction between people and the environments in which they find themselves" (Billsberry et al., 2005, cited Lewin, 1952). Implicit in the model developed for this research is the assumption that personal and systemic characteristics of the organization influence the behavioural attitudes and outcomes of the individual. This perspective is known as interactionism and is distinguishable from the more traditional modes of inquiry: the individual difference approach and the situational approach (Chatman, 1989).

The interactionist perspective enables us to postulate a link between an individual's assessment of the environment perceptions of overall PO-fit, and the resultant job satisfaction and turnover intentions. Further, we side with the view that perceptions of the work environment by individual employees are the most relevant antecedents of individual outcomes (Kristof-Brown and Jansen, 2007). This research therefore focuses upon individual perceptions of their work environment, which we conceptualized to include perceptions of their own person-organization fit and CSP assessments of their organization (hereafter CSPA). 


\section{Hypotheses}

Job seekers, it is often claimed, evaluate the fit between an organization's values and their own, with better fit leading to a higher likelihood of job acceptance intentions (Cable and Judge, 1996). Similarly, organizations make efforts to assess candidates' likely fit with the company during the recruitment phase because person-organization values fit is a predictor of many successful work outcomes (Cable and Judge, 1997).

If the values represented by CSR are representative of some universally accepted values, then we would expect CSP to have a generally positive effect on PO-fit, despite individual or cultural variability in personal values and norms. Moreover, if CSR is linked to a set of universal values, one would also expect that an organization espousing CSR would be more likely to fulfil the general value expectations of its employees, and that good application of CSR principles will lead to more positive assessments of PO-fit.

It has been argued that individuals within an organization make judgments and develop perceptions about their organization's CSR performance and that such performance can "trickle down to affect employees' subsequent attitudes and behaviours" (Rupp et al., 2006: 537). We suggest that the mechanism for this trickle-down effect is through the relationship between these CSP judgements and perceived PO-fit. There is little research that has attempted to make an explicit link between CSP and PO-fit, although it is often assumed that good CSR performance will 'naturally' lead to better CSPA and fit. In a closely-related research stream, however, some scholars did find a relationship between the perceived ethical climate of a firm and perceived PO-fit (Ambrose et al., 2008). In addition, Coldwell et al. (2008) have developed the construct of ethical fit as a dimension of PO-fit and relate this to other employee outcomes such as employee attraction and retention. Herrbach and Mignonac (2007) have also found supportive evidence that there is a tendency towards higher degrees of beneficial outcomes when employees perceive that their companies endorse ethical values. Hence, we suggest that positive employee assessment of CSP is related to heightened perceptions of person-organization fit, leading to our first hypothesis:

HYPOTHESIS 1: Higher scores on the employee assessment of Corporate Social Performance are positively related to perceived Person-Organization Fit.

A situation where personal values and goals do not match those of the organization is considered to be a poor PO-fit. Festinger's (1962) Theory of Cognitive Dissonance holds that individuals strive to minimize dissonance in their environment and that continued dissonance leads to dissatisfaction. This assertion is supported by a substantial body of research work (Adkins et al., 1996; Amos and Weathington, 2008), although some evidence fails to support 
this relationship (Rosete, 2006). However, on the balance of existing empirical evidence, we suggest that employees who perceive poor fit with the organization in terms of their values and goals would therefore be dissatisfied in their jobs. Furthermore, the opposite should also hold true. This notion, which has been tested extensively in the literature (Coldwell et al., 2008; Sims and Kroeck, 1994; Verquer et al., 2003), is nonetheless very relevant for the development of our model. Hence, this leads us to the following hypothesis:

HYPOTHESIS 2: Higher degrees of perceived Person-Organization Fit are positively related to employee Job Satisfaction.

Although some early studies did not find any correlation between ethical climate fit and turnover intentions (Sims and Kroek, 1994), more recently, correlations between PO-fit and turnover intentions have been observed (Ambrose et al., 2008). In general, employees who have ethical values compatible with their organizations are thought to fit better and to display a lower propensity to quit (Coldwell et al., 2008; Valentine et al., 2006). We therefore suggest:

HYPOTHESIS 3: Higher degrees of perceived Person-Organization Fit are negatively related to Turnover Intention.

There is a small, but growing body of research that explicitly links CSR to positive employee attitudes and behaviours (Gond et al., 2017). For example, Collier and Esteban (2007) and Brammer et al. (2007) relate CSR to employee commitment. Riordan et al. (1997) and Valentine and Fleischman (2008) found an empirical relationship between positive employee assessment of various CSR indicators and increased job satisfaction and reduced turnover intentions. We therefore hypothesize that:

HYPOTHESIS 4: Higher scores on the employee assessment of Corporate Social Performance are positively related to Job Satisfaction; and

HYPOTHESIS 5: Higher scores on the employee assessment of Corporate Social Performance are negatively related to Turnover Intention.

Finally, the relationship between job satisfaction and turnover intention is well established in the HRM/management literature (Tett and Meyer, 1993; Harrison et al., 2006). Both scholars and human resource management practitioners have long viewed the fostering of employee job satisfaction as a critical factor that determines such outcomes as higher employee commitment, better job performance and low employee turnover intentions: The following hypothesis is therefore proposed:

HYPOTHESIS 6: Higher degrees of Job Satisfaction are negatively related to Turnover Intention.

The hypotheses given above are summarized in our initial research model (Figure 1). 
FIGURE 1

Initial Research Model

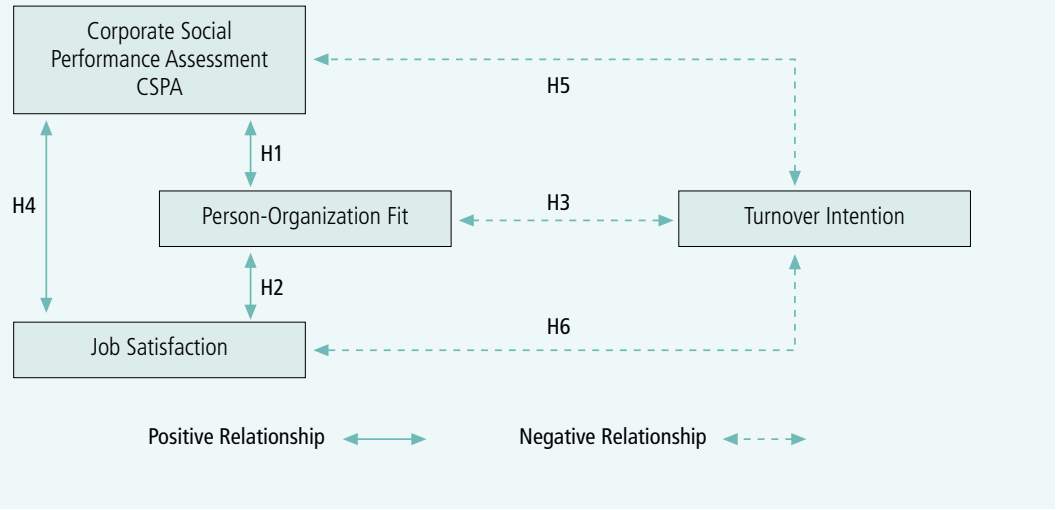

\section{Method}

\section{Data collection}

Data were obtained from an online survey of mainly young employees of companies from multiple sectors. A snowball sample from international school alumni and contacts of postgraduate students was used. Respondents were invited by e-mail to respond to the survey online and to send the hyperlink on to other suitable candidates. 1354 e-mails were sent directly, but it is not known how many invitations were sent on to other respondents. A direct response rate can be calculated of $31 \%$, a fairly standard rate for online and e-mail based surveys (Deutskens et al., 2004), but the figure may be lower than this due to the aforementioned snowballing effect. Out of the 419 responses received, 317 were considered suitable for analysis after cleaning the dataset, which excluded data from identical IP addresses, outliers and cases with over $10 \%$ of data missing. The data retained represent $76 \%$ of the initial sample.

The final sample consisted of roughly equal numbers of male $(49 \%)$ and female (51\%) respondents, 57\% from European and over a third from Chinese companies. The remainder of the responses originated from other countries. Most of the respondents were in the under 25 age group (47\%), followed by the 25-35 age group (35\%) and the over 35 age group (18\%). In terms of employment, most of the respondents were employees (77\%), followed by middle managers (11\%), executives (4\%) and others. A fairly even spread of company size was represented, half being SMEs and the other half, large companies of over 250 employees. Table 1 describes the sample composition. 
TABLE 1

Sample Composition

\begin{tabular}{|c|c|c|c|c|}
\hline \multirow[t]{2}{*}{ Gender } & Male & Female & & \\
\hline & $154(49 \%)$ & $162(51 \%)$ & & \\
\hline \multirow[t]{2}{*}{ Age } & $<25$ & $25-35$ & $35+$ & \\
\hline & $147(47 \%)$ & $112(35 \%)$ & $57(18 \%)$ & \\
\hline \multirow[t]{2}{*}{ Nationality } & European & Chinese & Other & \\
\hline & $180(57 \%)$ & $114(36 \%)$ & $23(7 \%)$ & \\
\hline \multirow[t]{2}{*}{ Position } & Employee & Middle Manager & Executive & Other \\
\hline & $243(77 \%)$ & $34(11 \%)$ & $24(8 \%)$ & $16(4 \%)$ \\
\hline \multirow[t]{2}{*}{ Number of employees } & $<250$ & $250+$ & & \\
\hline & $163(51 \%)$ & $154(49 \%)$ & & \\
\hline
\end{tabular}

\section{Measurement}

The two dependent variables, Job Satisfaction and Turnover Intention were measured using the 3 and 4 item seven-point Likert scales developed by McNichols et al. (1978) and Cammann et al. (1979) respectively. Confirmatory factor analysis with Varimax rotation showed that one of the items from the job satisfaction scale measuring comparison of how one likes one's job compared to how others like theirs, did not load satisfactorily onto the scale and so was not used in subsequent analyses. The final factor analysis explained $67 \%$ of the variance. The KMO measure of sampling adequacy yielded a good score of 0.83 and the Bartlett's test of sphericity was significant. Inter-item reliability for the two scales was good, with Cronbach alphas of $\alpha=0.74$ for the Job Satisfaction scale and $\alpha=0.84$ for the Turnover Intention scale.

The two-dimensional independent variable PO-fit was measured using a six-item scale that captured both perceived goal and value congruence. Three from measures used by Money and Graham (1999) for the dimension of value congruence and the other three items were created for the dimension of goal congruence. Since the study was intended to be applicable across different company types with a diversity of possible values, measures asked respondents to evaluate fit in general terms of values and goals without defining them specifically. PO goals fit was measured with three items: 'Others in my organization would likely score their goals the same as me'; 'I share the same goals as others in my organization' and 'I share the same goals as others where I work.' PO values fit used 'Working for this company gives me the opportunity to strive for values in which I really believe'; 'In a sense, the company's policies are based on values that are similar to mine'; 'Overall, values that are important to the company 
are important to me.' A 7-point Likert scale anchored by 'strongly agree' and 'strongly disagree' was used. Inter-item reliability for the whole scale was satisfactory at $\alpha=0.76$.

Pre-tests of this scale were conducted on a sample of 58 international students. Exploratory factor analysis showed factor loadings $>0.7$ for all items on two components, one corresponding to a values dimension and the other to a goals dimension. Kaiser-Meyer-Olkin measure of sampling adequacy was .72, above the recommended value of .6, and Bartlett's test of sphericity was significant $\left(\chi^{2}(15)=39.76, p<.001\right)$.

Scores for employee assessment of Corporate Social Performance (CSPA) were measured using the Environmental and Social Ratings criteria developed by KLD Research Associates, Inc. (KLD Research, 2007). Respondents were asked to assess their company performance on seven environmental criteria including energy use, pollution prevention and recycling, as well as environmental management systems in use. Eighteen items based on social criteria were used: two items on performance in the community, which included helping the community and charitable giving; four on diversity issues enquiring about the position of women, disabled workers and minorities in the company and work/life balance; seven on employee relations, which assessed company performance on such issues as health and safety and retirement programs, union relations, participative management and cash profit-sharing; two on human rights evaluating labour rights in the supply chain and relations with local people and three statements of product quality, R\&D and innovation.

Scores for assessment of Corporate Social Performance were calculated by summing the evaluations as -1 for negative assessments, 0 for no opinion and +1 for positive assessment for each of the dimensions, then summing the total. The mean of the final score is reported out of 7 in this study for the purpose of clear presentation.

\section{Results and Analysis}

\section{Initial analysis}

All analyses were performed using SPSS and AMOS. The data were first examined for normality, and the means and standard deviations calculated. The results are shown in Table 2.

None of the variables displayed normal distribution, so initial analyses used non-parametric Spearman's rho correlations to test the hypotheses. All hypothesized correlations between the variables were significant at the $p<0.01$ level. Hypothesis 1: Higher scores on the assessment of Corporate Social Performance are positively related to Person-Organization Fit is supported, a fairly 
TABLE 2

Mean Values for Dependent and Independent Variables

\begin{tabular}{lcc} 
& Mean $(\bar{x})$ & Standard Deviation (S) \\
Turnover Intention & 3.56 & 1.0 \\
\hline Job Satisfaction & 4.82 & 0.57 \\
\hline Person-Organization Fit & 4.86 & 0.53 \\
\hline Corporate Social Performance Assessment & 4.52 & 1.49 \\
\hline
\end{tabular}

strong positive correlation coefficient of 0.582 being obtained. Hypothesis 2: Higher degrees of Person-Organization Fit are positively related to employee Job Satisfaction is also supported with a fairly strong positive correlation coefficient of 0.518. Hypothesis 3, which posits a negative relationship between PO-fit and Turnover Intention is also supported, with a medium negative correlation coefficient of -0.368 . Hypothesis 4: Higher scores on the employee assessment of Corporate Social Performance are positively related to Job Satisfaction yields a weak positive correlation of 0.290 . Hypothesis 5 postulates: Higher scores on the employee assessment of Corporate Social Performance are negatively related to Turnover Intention, and obtains a weak but significant correlation of -0.223 . Finally, a strong negative correlation is obtained for the relationship between Job Satisfaction and Turnover Intention, with a coefficient of -0.604 , lending support to hypothesis 6: Higher degrees of Job Satisfaction are negatively related to Turnover Intention. The correlation matrix is shown in Table 3.

\section{Analysis of the initial research model}

Next, we used Structural Equation Modelling (SEM) to test our initial research model (Figure 1). The dataset had no missing values and therefore modification indices were inspected and bootstrapping techniques were applied for all model analyses (Arbuckle, 2008). We examined the measurement model first for

\section{TABLE 3}

Spearman's rho Correlation Coefficients

\section{CSPA}

PO fit

Turnover Intention

\begin{tabular}{llcc} 
PO fit & $\left.0.582^{(*}\right)$ & - & - \\
\hline Turnover Intention & $-0.223\left(^{* *}\right)$ & $-0.368\left(^{* *}\right)$ & - \\
\hline Job Satisfaction & $\left.0.290{ }^{* *}\right)$ & $0.518\left(^{* *}\right)$ & $-0.604\left(^{* *}\right)$ \\
\hline
\end{tabular}

** Significant at the 0.01 level 
discriminant validity of the three constructs PO-fit, Job Satisfaction and Turnover Intention through a comparison of the average variance extracted (AVE) and the square of the correlations between the latent constructs, ensuring that the former yielded higher values than the latter across all constructs (Anderson and Gerbing, 1998). Convergent validity was also verified, with AVE higher than 0.5 (Fornell and Larcker, 1981). The results displayed in Table 4 show that construct discriminant and convergent validity are both satisfactory.

TABLE 4

Discriminant Validity of Constructs

\begin{tabular}{lccc} 
Constructs & PO fit & Job Satisfaction & Turnover Intention \\
\hline PO fit & $\mathbf{0 . 6 0}$ & - & - \\
\hline Job Satisfaction & 0.36 & $\mathbf{0 . 7 1}$ & - \\
\hline Turnover Intention & 0.19 & 0.45 & $\mathbf{0 . 8 1}$ \\
\hline
\end{tabular}

Average Variance Extracted (AVE) in bold on diagonal. Squared correlations on white background.

The fit scores for the measurement model were $\chi^{2}=59.15$, d.f. $=29$ yielding a normal $\chi^{2}=$ of 2.04 with $p=0.001(n=317)$, the $C F I=0.973$ (comparative fit index), and the RMSEA $=0.057$ (root mean square error of approximation) with LO $90=0.036, \mathrm{HI} 90=0.078$ and PCLOSE $=0.262$. These are quite satisfactory results for a dataset of this size (Hair et al., 2006).

The initial structural model results (Figure 1) showed that three paths are not significant. These were: 1 - the hypothesized negative relationship $(\mathrm{H} 3)$ between higher PO-fit and Turnover Intention (-0.02, $p=0.88)$; 2 - the hypothesized positive relationship $(\mathrm{H} 4)$ between CSPA and Job Satisfaction $(-0.11, p=0.35)$; and 3- the hypothesized negative relationship (H5) between higher CSPA and Turnover Intention $(-0.04, p=0.61)$.

\section{Proposed model for the influence of CSPA on PO-fit, job satisfaction and turnover intention}

A closer look at the results of the correlations and SEM results displayed in Table 3 strongly suggests a mechanism by which corporate social performance may be having an influence on job satisfaction and turnover intention, namely through a heightened perception of person-organization fit. We can see that the correlation coefficients between: 1- CSPA and 2- job satisfaction and turnover intention are weak ( 0.290 and -0.223 respectively), whereas those between: 1PO-fit; and 2- job satisfaction and turnover intention are both clearly stronger (0.518 and -0.368 respectively). In addition, we see a high correlation between 
PO-fit and CSPA. These results lead to the idea that job satisfaction and turnover intention are related to person-organization fit and that, in turn, enhanced PO-fit is linked to higher perceived corporate social performance. CSPA seems to matter in relation to PO-fit.

In view of these results, we decided to test this proposed mechanism by modelling the suspected linear pathway mechanism, i.e. CSPA $\rightarrow$ PO-fit $\rightarrow$ Job Satisfaction $\rightarrow$ Turnover Intention. However, in order to rule out competing explanations, we also modelled other potential models to determine which displays the best fit with our data. From this comparison, we determined the suggested mechanism described above is the most plausible one as the model fit is superior to alternative explanations and non-significant relationships are not present.

\section{Structural model}

Thus, following the successful testing of the measurement model, and ruling out competing explanations, the final model was accepted as the best structural model. The results of the SEM analysis for this model are shown in Figure 2.

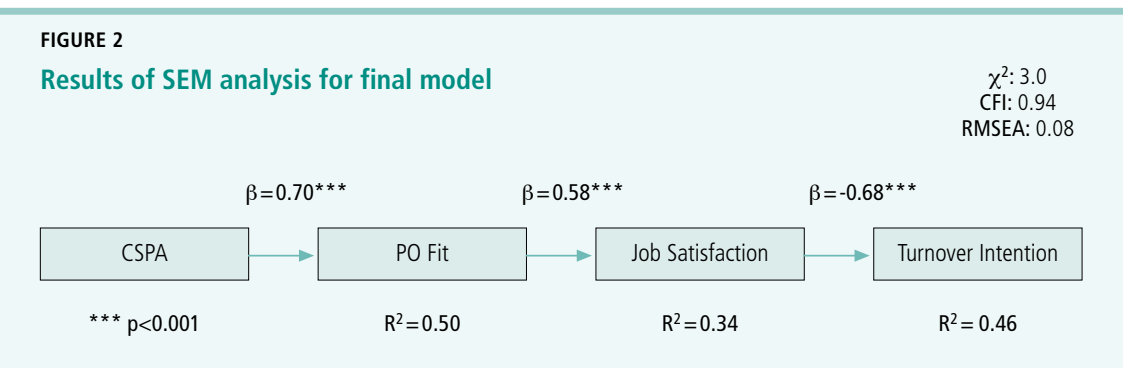

The model demonstrated good fit with a normal $\chi^{2}=3.00$, the upper limit associated with better fitting models. The $\mathrm{CFI}=0.94$ was above the 0.9 level typically considered as an indication of good fit, and RMSEA was at a good level at 0.08, with LO $90=0.03, \mathrm{HI} 90=0.074$ and PCLOSE $=0.368$ (Arbuckle, 2008; Hair et al., 2006).

These results confirm those suggested by the initial correlation analysis; CSPA is not having a direct influence on job satisfaction and employee turnover intention, but it is acting through a knock-on effect by influencing perceptions of PO-fit that, in turn, is playing a direct role in improved job satisfaction and lowered turnover intention. We were reminded of Rupp et al.'s conjecture of the existence of a trickle-down effect regarding CSP and employee outcomes (Rupp et al., 2006). The relatively low $R^{2}$ values show that PO-fit plays a significant but relatively minor part in predicting job satisfaction and turnover intention. 
Other predictors of these variables are well documented in the human resources management/organizational behaviour literature and were not the focus of this investigation.

\section{Bias tests}

Bias tests were performed on the data in order to investigate whether gender, nationality, or organization size was influencing any of the independent or dependent variables. Mann-Whitney $U$ tests showed no significant differences due to gender or company size for any of the variables. This is in contrast to some previous studies that have indicated that women show higher sensitivity to corporate social responsibility issues than men (Brammer et al., 2007).

There were, however, significant differences in employee assessment of corporate social performance between Chinese and European respondents, with the mean values of the CSPA score at 4.88 and 4.34 respectively, indicating that the Chinese respondents rated their companies' CSP higher than European respondents: a Z-value of -3.31 was obtained at a significance level of $p<0.01$. Conversely, the mean values for job satisfaction were higher for European than for Chinese respondents, at 4.96 and 4.66 respectively, with a Z-value of -3.38 at a significance level of $p<0.01$.

A potential and controversial bias of this study stems from our use of the same time period, and similar instrument formats, for collecting data about employees' assessments of CSPA, perceived PO-fit, Job Satisfaction and Turnover Intention. A common preconception is that this may have induced a halo effect or common method bias (CMB), as described by Kristof-Brown and Jansen (2007).

The supposed result of this potential bias was that these essentially simultaneous evaluations may have led to inflated correlation coefficients. Similarly, inflated correlation results may be expected from the possibility that employees seek to limit their cognitive dissonance in rating their employers' CSP when they feel they are a good fit for their firm and enjoy their work. However, Brammer et al. (2007) suggest that research focusing on different forms of CSR (as done in the $\mathrm{KLD}$ ratings criteria) might lessen this bias.

Perhaps more importantly, recent results of Conway and Lance (2010) indicate common method bias does not in fact routinely upwardly inflate coefficients; it might equally attenuate them. Lance et al. (2010) concluded that same-method observed score correlations are actually quite accurate representations of their true-score counterparts. We acknowledge the potential for this bias and examined it using SEM in order to assess its actual magnitude in this research. We used the common latent factor method with AMOS (Meade et al., 2007). Results indicated that common method bias explains only $2.2 \%$ of the total variance. Fortunately, 
the model did not have identification problems sometimes encountered when using this method to assess this bias. Thus, we concluded CMB to be minimal and can be considered to have a minor impact on our findings. Furthermore, the data collection method made this minor bias inevitable, as we could not realistically consider coordinating a time delay between employees' assessment of CSP, perceived PO-fit, Job Satisfaction and Turnover Intentions in a voluntary online data collection scenario.

\section{Discussion and Conclusions}

As companies are moving steadily towards the integration of CSR into corporate strategy and policy, it is becoming more and more important for them to understand the mechanisms by which these policies can yield value. There are very few empirical studies which have investigated the influence of CSP on employees and so the results of this study, based on individuals working in different sectors, will help contribute to extant knowledge in this area. Our results show that young, non-managerial employees perceived that positive performance in the various areas of CSP may be having a significant influence on their perception of how they fit overall with the values and goals of the company. This might be useful news to senior managers who have not been previously concerned with CSP, but nonetheless wish to attract and retain valuable employees.

The fact that positive assessments of corporate social performance have a strong link to increased perceived PO-fit on the dimensions of values and goals can be explained if corporate social performance is regarded as the manifested application of stated values and goals in areas such as responsibility towards the environment, good managerial practice in HR, and responsibility towards multiple stakeholders in business and society. Employees assess corporate social performance and interpret it as the corporate value system and goals the company is actually attempting to achieve. The resultant degree of congruence of company values with those of its employees is, in turn, positively influencing their job satisfaction and also contributing to lower turnover intentions.

The implications of these findings are that while good performance in corporate social responsibility may not be immediately obvious in financial terms, its implementation in business is worthwhile because it seems to reinforce the perception of employees that their values fit with those of the organization. This creates value in terms of increased job satisfaction and reduced employee turnover intentions. It should be noted, however, that in this paper only the perceptions of employees on these issues are measured. Simply improving CSP objectively, without involving and raising awareness among employees, will not necessarily lead to improved perceptions of how the employee fits within the organization. 
This study establishes only that when employees perceive the company to be acting responsibly on a set of criteria, their feelings of fit are enhanced.

The study is subject to some limitations and points to several possible future directions. Firstly, the KLD index may not be an ideal employee assessment of their company's performance, as several of the items border on strategic, or are technical in nature, and may not be easily apprehended internally by people that are not in more senior positions in the company. Another concern about the KLD index is that it is an index and not a construct by design, so checking for consistency in responses through reliability testing may not be appropriate. A valid question also remains regarding the comprehensiveness of the index, and whether it is appropriate for all businesses or sectors of activity. Finally, the use of the KLD criteria for measurement of CSP is controversial. According to Wood and Jones (1995), the numerical ratings are a crude measure and often based on qualitative assessments of the performance of the company. In spite of this, we considered that this methodology is one of the few available ways of assessing CSP with sufficient scope, and it has been quoted as being "the de facto research standard for measuring CSP" in academic research (Waddock, 2003: 369), and has experienced a growing acceptance amongst the research community (Simerly, 2003).

The second limitation concerns non-probability sampling techniques. The educational homogeneity that may exist in this sample could mean that the respondents might adhere more strongly to the values of CSR, or that their levels of job satisfaction and feelings of fit differ from other socio-economic groups. It may be useful in future to concentrate on simply assessing one aspect of CSP at a time in order to increase the validity and the reliability of the results. The disadvantage of this, however, lies in the reduction of the scope of such studies, and the ability to investigate total effects of corporate social and environmental responsibility. More specifically, employees' global assessment of CSP would become un-examinable in relation to employee outcomes. It may be unlikely that one aspect of CSP alone normally would bear significant implications for employee outcomes.

A future project might attempt different data collection approaches. It would be interesting to extend this investigation to age groups other than the relatively young participants in this study, or to pre-specified sectors of business activity. Future research might attempt a broad data collection approach that does not rely on the internet and snowball sampling in order to use, for example, stratified random sampling. Another interesting avenue of research would be to monitor, in a longitudinal study, how CSPA and its relationships to PO-fit and job satisfaction change over time as the individual matures and the relationship with his or her organization develops. 
Future research might also examine further the role of gender in CSPA and sensitivity to CSR issues. This study provides contradictory evidence to recent and related work (Brammer et al., 2007). It is possible that age or even culture moderate CSPA. There is still much more empirical work to be done in this area, especially in terms of comparing organizations operating in different socioeconomic contexts, their own adaptation to their specific CSR environment and their related CSP, and of course, employees' outcomes in these contexts.

\section{References}

Adkins, Cheryl L., Elizabeth C. Ravlin, and Bruce M. Meglino (1996) "Value Congruence between Co-Workers and its Relationship to Work Outcomes." Group and Organization Management, 21 (4), p. 439-460.

Albinger, Heather Schmidt and Sarah J. Freeman (2000) "Corporate Social Performance and Attractiveness as an Employer to Different Job Seeking Populations." Journal of Business Ethics, 28 (3), p. 243-253.

Ambrose, Maureen L., Anke Arnaud, and Marshall Schminke (2008) "Individual Moral Development and Ethical Climate: The Influence of Person-Organization Fit on Job Attitudes." Journal of Business Ethics, 77 (3), p. 323-333.

Amos, Elizabeth A. and Bart L. Weathington (2008) "An Analysis of the Relation between Employee Organization Value Congruence and Employee Attitudes." The Journal of Psychology, 142 (6), p. 615-632.

Anderson, James C. and David W. Gerbing (1988) "Structural Equation Modeling in Practice: A Review and Recommended Two-Step Approach." Psychological Bulletin, 103 (3), p. 411 423.

Arbuckle, James L. (2008) Amos ${ }^{T m} 17.0$ User's Guide, Chicago, II: SPSS.

Billsberry, Jon, Véronique Ambrosini, John Moss-Jones, and Philip Marsh (2005) "Some Suggestions for Mapping Organizational Members' Sense of Fit." Journal of Business and Psychology, 19 (4), p. 555-570.

Brammer, Stephen, Andrew Millington, and Bruce Rayton (2007) "The Contribution of Corporate Social Responsibility to Organizational Commitment." The International Journal of Human Resource Management, 18 (10), p. 1701-1719.

Cable, Daniel M. and Timothy A. Judge (1997) "Interviewers' Perceptions of Person-Organization Fit and Organizational Selection Decisions." Journal of Applied Psychology, 82 (4), p. 546561.

Cable, Daniel M. and Timothy A. Judge (1996) "Person-Organization Fit, Job Choice Decisions, and Organizational Entry." Organizational Behavior and Human Decision Processes, 67 (3), p. 294-311.

Cammann, Cortlandt, Mark Fichman, Douglas Jenkins, and John Klesh (1979) "The Michigan Organizational Assessment Questionnaire." In Cook, J.D., Hepworth, S.J., Wall, T.D. and Warr, P.B. (Eds.), The Experience of Work, London, UK: The Academic Press.

Carroll, Archie B. (1979) "A Three-dimensional Conceptual Model of Corporate Performance." Academy of Management Review, 4 (4), p. 497-505. 
Carroll, Archie B. and Ann Buchholtz (2000) Business and Society: Ethics and Stakeholder Management, Cincinnati, OH: South-Western Educational Publishing.

Chatman, Jennifer A. (1989) "Improving Interactional Organizational Research: A Model of Person-Organization Fit." Academy of Management Review, 14 (3), p. 333-349.

Chen, Pei, Paul Sparrow, and Cary Cooper (2016) "The Relationship between Person-Organization Fit and Job Satisfaction." Journal of Managerial Psychology, 31 (5), p. 946-959.

Clarkson, Max E. (1995) "A Stakeholder Framework for Analyzing and Evaluating Corporate Social Performance." Academy of Management Review, 20 (1), p. 92-117.

Colbert, Amy E., Amy L. Kristof-Brown, Bret H. Bradley, and Murray R. Barrick (2008) "CEO Transformational Leadership: The Role of Goal Importance Congruence in Top Management Teams." Academy of Management Journal, 51 (1), p. 81-96.

Coldwell, David A.L., Jon Billsberry, Nathalie Van Meurs, and Philip J.G. Marsh (2008) "The Effects of Person-Organization Ethical Fit on Employee Attraction and Retention: Towards a Testable Explanatory Model." Journal of Business Ethics, 78 (4), p. 611-622.

Collier, Jane and Rafael Esteban (2007) "Corporate Social Responsibility and Employee Commitment." Business Ethics: A European Review, 16 (1), p. 19-33.

Conway, James M. and Charles E. Lance (2010) "What Reviewers Should Expect from Authors Regarding Common Method Bias in Organizational Research." Journal of Business and Psychology, 25 (3), p. 325-334.

De Roeck, Kenneth, Assâad El Akremi, and Valérie Swaen (2016) "Consistency Matters! How and When Does Corporate Social Responsibility Affect Employees' Organizational Identification?" Journal of Management Studies, 53 (7), p. 1141-1168.

Deutskens, Elisabeth, Ko De Ruyter, Martin Wetzels, and Paul Oosterveld (2004) "Response Rate and Response Quality of Internet-Based Surveys: An Experimental Study." Marketing Letters, $15(1)$, p. 21-36.

Donaldson, Thomas and Lee E. Preston (1995) "The Stakeholder Theory of the Corporation: Concepts, Evidence, and Implications." Academy of Management Review, 20 (1), p. 65-91.

Festinger, Leon (1962) A Theory of Cognitive Dissonance. Vol. 2. Redwood City, Ca: Stanford University Press.

Fornell, Claes and David F. Larcker (1981) "Evaluating Structural Equation Models with Unobservable Variables and Measurement Error." Journal of Marketing Research, 18 (1), p. 39-50.

Gond, Jean-Pascal, Assâad El Akremi, Valérie Swaen, and Nishat Babu (2017) "The Psychological Microfoundations of Corporate Social Responsibility: A Person-Centric Systematic Review." Journal of Organizational Behavior, 38 (2), p. 225-246.

Greening, Daniel W. and Daniel B. Turban (2000) "Corporate Social Performance as a Competitive Advantage in Attracting a Quality Workforce." Business and Society, 39 (3), p. 254-280.

Hair, Joseph F., William C. Black, Barry J. Babin, Rolp E. Anderson, and Ronald L. Tatham (2006) Multivariate Data Analysis ( $6^{\text {th }} E d$.). Upper Saddle River, New Jersey: Prentice-Hall Inc.

Harrison, David A., Daniel A. Newman, and Philip L. Roth (2006) "How Important are Job Attitudes? Meta-Analytic Comparisons of Integrative Behavioral Outcomes and Time Sequences." Academy of Management Journal, 49 (2), p. 305-325. 
Herrbach, Olivier, and Karim Mignonac (2007) "Is Ethical P-O Fit Really Related to Individual Outcomes? A Study of Management-Level Employees." Business and Society, 46 (3), p. 304330.

Jones, David A., Chelsea R. Willness, and Sarah Madey (2014) "Why Are Job Seekers Attracted by Corporate Social Performance? Experimental and Field Tests of Three Signal-Based Mechanisms." Academy of Management Journal, 57 (2), p. 383-404.

KLD Research (2007) "Environmental, Social and Governance Ratings Criteria." Boston, MA: KLD Research and Analytics Inc.

Kristof-Brown, Amy L. and Karen J. Jansen (2007) "Issues of Person-Organization Fit," In Ostroff, C. and Judge, T.A. (Eds.), Perspectives on Organizational Fit, Oxford, UK: Lawrence Erlbaum Associates.

Lance, Charles E., Bryan Dawson, David Birkelbach, and Brian J. Hoffman (2010) "Method Effects, Measurement Error, and Substantive Conclusions." Organizational Research Methods, 13 (3), p. 435-455.

Lee, Eun Mi, Seong-Yeon Park, and Hyun Jung Lee (2013) "Employee Perception of CSR Activities: Its Antecedents and Consequences." Journal of Business Research, 66 (10), p. 1716-1724.

McNichols, Charles W., Michael J. Stahl, and T. Roger Manley (1978) "A Validation of Hoppock's Job Satisfaction Measure." Academy of Management Journal, 21 (4), p. 737-742.

Meade, A.W., Watson, A.M. and Kroustalis, C.M. (2007) "Assessing Common Method Bias in Organizational Research." Paper Presented at the $22^{\text {nd }}$ Annual Meeting of the Society for Industrial and Organizational Psychology, New York, NY.

Money, R. Bruce and John L. Graham (1999) "Salesperson Performance, Pay, and Job Satisfaction: Tests of a Model using Data Collected in the United States and Japan." Journal of International Business Studies, 30 (1), p. 149-172.

Morgeson, Frederick P., Herman Aguinis, David A. Waldman, and Donald S. Siegel (2013) "Extending Corporate Social Responsibility Research to the Human Resource Management and Organizational Behavior Domains: A Look to the Future." Personnel Psychology, 66 (4), p. 805-824.

Ostroff, Cheri and Mathis Schulte (2007) "Multiple Perspectives of Fit in Organizations across Levels of Analysis." In Ostroff, C. and Judge, T.A. (Eds.), Perspectives on Organizational Fit, Oxford, UK: Lawrence Erlbaum Associates.

Riordan, Christine M., Robert D. Gatewood, and Jodi Barnes Bill (1997) "Corporate Image: Employee Reactions and Implications for Managing Corporate Social Performance." Journal of Business Ethics, 16 (4), p. 401-412.

Rosete, David (2006) "The Impact of Organisational Values and Performance Management Congruency on Satisfaction and Commitment." Asia Pacific Journal of Human Resources, $44(1)$, p. $7-24$.

Rupp, Deborah E., Jyoti Ganapathi, Ruth V. Aguilera, and Cynthia A. Williams (2006) "Employee Reactions to Corporate Social Responsibility: An Organizational Justice Framework." Journal of Organizational Behavior, 27 (4), p. 537-543.

Rupp, Deborah E., Ruodan Shao, Meghan A. Thornton, and Daniel P. Skarlicki (2013) "Applicants' and Employees' Reactions to Corporate Social Responsibility: The Moderating Effects of FirstParty Justice Perceptions and Moral Identity." Personnel Psychology, 66 (4), p. 895-933. 
Shaw, Jason D., Michelle K. Duffy, Jonathan L. Johnson, and Daniel E. Lockhart (2005) "Turnover, Social Capital Losses, and Performance." Academy of Management Journal, 48 (4), p. 594606.

Simerly, Roy L. (2003) "An Empirical Examination of the Relationship Between Management and Corporate Social Performance." International Journal of Management, 20 (3), p. 353-359.

Sims, Randi L. and K. Galen Kroeck (1994) "The Influence of Ethical Fit on Employee Satisfaction, Commitment and Turnover." Journal of Business Ethics, 13 (12), p. 939-947.

Tett, Robert P. and John P. Meyer (1993) "Job Satisfaction, Organizational Commitment, Turnover Intention, and Turnover: Path Analyses Based on Meta-Analytic Findings." Personnel Psychology, 46, (2), p. 259-293.

Turban, Daniel B., and Daniel W. Greening (1997) "Corporate Social Performance and Organizational Attractiveness to Prospective Employees." Academy of Management Journal, 40 (3), p. 658-672.

Valentine, Sean and Gary Fleischman (2008) "Ethics Programs, Perceived Corporate Social Responsibility and Job Satisfaction." Journal of Business Ethics, 77 (2), p. 159-172.

Valentine, Sean, Martin M. Greller, and Sandra B. Richtermeyer (2006) "Employee Job Response as a Function of Ethical Context and Perceived Organization Support." Journal of Business Research, 59 (5), p. 582-588.

Vancouver, Jeffrey B., and Neal W. Schmitt (1991) "An Exploratory Examination of PersonOrganization Fit: Organizational Goal Congruence." Personnel Psychology, 44 (2), p. 333-352.

Verquer, Michelle L., Terry A. Beehr, and Stephen H. Wagner (2003) "A Meta-Analysis of Relations between Person-Organization Fit and Work Attitudes." Journal of Vocational Behavior, 63 (3), p. 473-489.

Vlachos, Pavlos A., Nikolaos G. Panagopoulos, and Adam A. Rapp (2014) "Employee Judgments of and Behaviors toward Corporate Social Responsibility: A Multi-Study Investigation of Direct, Cascading, and Moderating Effects." Journal of Organizational Behavior, 35 (7), p. 990-1017.

Waddock, Sandra (2003) "Myths and Realities of Social Investing." Organization \& Environment, $16,(3)$, p. 369-380.

Wang, Yijing and Guido Berens (2015) "The Impact of Four Types of Corporate Social Performance on Reputation and Financial Performance." Journal of Business Ethics, 131 (2), p. 337-359.

Wartick, Steven L. and Philip L. Cochran (1985) "The Evolution of the Corporate Social Performance Model." Academy of Management Review, 10 (4), p. 758-769.

Wood, Donna J. (1991) "Corporate Social Performance Revisited." Academy of Management Review, 16 (4), p. 691-718.

Wood, Donna J. and Raymond E. Jones (1995) "Stakeholder Mismatching: A Theoretical Problem in Empirical Research on Corporate Social Performance." The International Journal of Organizational Analysis, 3 (3), p. 229-267.

Wu, Meng-Ling (2006) "Corporate Social Performance, Corporate Financial Performance, and Firm Size: A Meta-Analysis." Journal of American Academy of Business, 8 (1), p. 163-171.

Zyglidopoulos, Stelios, Peter Williamson, and Pavlos Symeou (2016) "The Corporate Social Performance of Developing Country Multinationals." Business Ethics Quarterly, 26 (03), p. 379-406. 


\section{SUMMARY}

\section{Individuals' Assessment of Corporate Social Performance, Person-Organization Values and Goals Fit, Job Satisfaction and Turnover Intentions}

Recent research in the domain of corporate social responsibility (CSR) has underlined the importance of moving away from an institutional perspective of CSR towards research at the micro-level. Such calls have insisted on the necessity of a developing a deeper, and more nuanced understanding of its impacts and mechanisms at the individual level. This paper addresses this issue by focusing on the nexus between how employees judge their companies' actual CSR performance and how that judgement can affect individual, micro-level outcomes such as job satisfaction and turnover intentions. We study this by a consideration of how perceived fit between employees and their organization mediates the relationship between perceived corporate social performance (CSP) on the one hand, and job satisfaction and turnover intentions on the other.

While there is a notion, commonly embraced in the literature, that corporate social performance can have beneficial effects on individual employee outcomes, there have not been many empirical studies looking into the mechanisms by which this occurs. Through a survey of 317 young employees from differing company sizes and sectors in Europe and Asia, we find that positive assessment of CSP does not have a direct influence on job satisfaction and turnover intention, but is mediated by person-organization fit. The latter, in turn, has a positive effect on job satisfaction and reduced turnover intention.

The implications of these findings are that the achievement of efficient and effective performance in social and environmental terms reinforces the perception of employees that their values fit with those of the organization. This process then creates value in terms of increased job satisfaction and reduced employee turnover intentions. We note also that simply improving CSP objectively, without involving and raising awareness among employees, will not necessarily lead to improved perceptions of how the employee fits within the organization and the potential positive knock-on employee outcomes.

KEYWORDS: corporate social performance, corporate social responsibility, personorganization fit (PO fit), job satisfaction, structural equation modelling (SEM), turnover intention. 


\section{RÉSUMÉ}

\section{Appréciation de la performance sociale de l'entreprise} par les employés, adéquation employé-organisation en matière de valeurs et d'objectifs, satisfaction au travail et intention de quitter son emploi

Des recherches récentes dans le domaine de la responsabilité sociale de l'entreprise (RSE) ont souligné l'importance de ne pas se limiter à une perspective purement institutionnelle de la RSE et de se tourner vers le niveau micro. Elles insistent également sur la nécessité de développer une compréhension plus approfondie, ainsi que plus nuancée, des impacts et des mécanismes sur les individus. Notre article prend en compte cet enjeu en s'attardant à l'étude de la relation entre l'appréciation que font les employés de l'actuelle RSE dans le cas de leur propre entreprise et la manière dont cette appréciation peut influer sur des résultats individuels ou de niveau micro, tels la satisfaction au travail et l'intention de quitter ou pas son emploi. Nous abordons cette question en étudiant la façon dont l'adéquation perçue entre les employés et leur organisation induit la relation entre la perception de la performance sociale de l'entreprise (PSE), d'une part, et la satisfaction au travail ou I'intention de quitter son emploi, d'autre part.

Une notion communément reprise dans la littérature soutient que la performance sociale des entreprises peut avoir des effets bénéfiques sur les employés au niveau individuel, cependant peu d'études empiriques se sont penchées sur les mécanismes en cause. Afin de combler cette lacune, nous analysons les données quantitatives d'une enquête menée auprès de 317 jeunes employés œuvrant dans des entreprises de tailles et de secteurs différents en Europe et en Asie. Nous observons qu'une appréciation positive de la PSE n'exerce pas une influence directe sur la satisfaction au travail ni sur l'intention de démissionner, mais qu'elle influe sur la relation employé-entreprise. Cette dernière, à terme, exerce une influence positive sur ces facteurs, soit la satisfaction au travail et l'intention de demeurer dans son emploi.

Ces résultats montrent qu'une performance efficiente et efficace de l'entreprise en ce qui a trait à ses responsabilités sociales et environnementales renforce la perception de la part des employés qu'il y a adéquation entre leurs valeurs et celles de l'entreprise. Ce processus crée donc de la valeur en augmentant la satisfaction au travail et en diminuant l'intention de quitter l'organisation. Nous avons également noté que le simple fait d'améliorer la PSE d'une manière objective, sans une implication et une conscientisation accrue des employés, ne mènera pas nécessairement à améliorer l'adéquation entre les employés et leur organisation ni aux résultats désirables auxquels on aurait pu s'attendre.

MOTS-CLÉS: performance sociale de l'entreprise, responsabilité sociale de l'entreprise, adéquation employé-organisation, satisfaction au travail, modélisation par équations structurelles, intention de démissionner. 


\section{RESUMEN}

\section{Evaluación individual del desempeño social de la empresa, adecuación persona-organización en cuanto a valores y objetivos, satisfacción del trabajo e intención de dejar su empleo}

Investigaciones recientes en el campo de la responsabilidad social de la empresa (RSE) han hecho resaltar la importancia de no limitarse a una perspectiva puramente institucional de la RSE y de abordar también el nivel micro. Dichas investigaciones insisten igualmente en la necesidad de desarrollar una comprensión más exhaustiva y perspicaz de sus impactos y mecanismos a nivel individual. Nuestro artículo toma en cuenta este punto crucial abordando el estudio de la relación entre la apreciación que hacen los empleados del real desempeño de la RSE en el caso de su propia empresa y la manera en que esta apreciación puede influenciar los resultados individuales o de micro nivel, tales como la satisfacción del trabajo y la intención de dejar su empleo. Estudiamos esta cuestión a través de la manera cómo la adecuación percibida entre los empleados y su organización actúa como mediador en la relación entre la percepción del desempeño social de la empresa (DSE), de un lado, y la satisfacción del trabajo y la intención de dejar su empleo, del otro lado.

Una noción comúnmente retomada en la literatura sostiene que el desempeño social de las empresas puede tener efectos benéficos sobre los empleados a nivel individual, sin embargo, pocos estudios empíricos han abordado los mecanismos por los cuales esto ocurre. Basándonos en el análisis de los datos cuantitativos de una encuesta llevada a cabo con 317 jóvenes empleados trabajadores de empresas de talla y sector diferentes en Europa y en Asia, constatamos que una apreciación positiva del desempeño social de la empresa (DES) no ejerce una influencia directa sobre la satisfacción del trabajo ni sobre la intención de dejar su empleo, pero está mediado por la relación empleado-empresa. Esta última, a su turno, ejerce una influencia positiva sobre dichos factores, es decir la satisfacción del trabajo y la intención de mantenerse en su empleo.

Estos resultados muestran que un desempeño eficiente y eficaz de la empresa en lo que refiere a sus responsabilidades sociales y ambientales refuerza la percepción de parte de sus empleados respecto a la presencia de adecuación entre sus valores y los valores de la empresa. Este proceso crea entonces un valor aumentando la satisfacción del trabajo y disminuyendo la intención de dejar la organización. Se notó igualmente que el simple hecho de mejorar el DSE de una manera objetiva, sin implicación ni concientización creciente de los empleados, no conducirá necesariamente a mejorar la adecuación entre los empleados y su organización ni a los resultados positivos à nivel individual que se hubiera podido esperar.

PALABRAS CLAVES: rendimiento social de la empresa, responsabilidad social de la empresa, adecuación empleado-organización, satisfacción del trabajo, modelización por ecuaciones estructurales, intención de dejar su empleo. 